\title{
Medieval Hunting as Training for War Insights for the Modern Swordsman
}

by Richard Swinney MD, FAAEM

P.O. Box 983

Nixa, Missouri USA 65714

TheRenaissanceMan@prodigy.net

Principal Instructor, Bramble Schoole of Defence

and

Scott Crawford RRT, BSEd

2744 E. Lindwood

Springfield, Missouri USA 65804

scott_crawford@sbcglobal.net

Director, Bramble Schoole of Defence

\begin{abstract}
Since antiquity, hunting (the pursuit of large game with dogs, swords, spears and bows) has been advocated as the best means of training men for war. The cognitive, psychological and physical demands of hunting in this fashion develop a fundamentally different skill set from that of standard modern Western Martial Arts training. Still legal in the United States, hunting wild boar employing medieval weapons and methods provides insights into swordsmanship readily available nowhere else.
\end{abstract}

Keywords - medieval, hunting, training, war, cognitive, psychological, physical, swordsmanship, sword, spear, wild boar

For a knight should always engage in anything to do with arms and chivalry, and if he cannot do so in war, he should do so in activities which resemble war. And the chase (bunting) is the most similar to war for these reasons: war demands expense, met without complaint; one must be well horsed and well armed; one must be vigorous, and do without sleep, suffer lack of good food and drink, rise early, sometimes have a poor bed, undergo cold and heat, and conceal one's fear.

King Alfonso XI of Castile (1312 - 1350 A.D.) Libro de la Monteria (Hunting Book of Alfonso XI) (Cummins, 2001: p. 4)

\section{INTRODUCTION}

The greatest limitation for modern historic Western Martial Artists is that we are a generation of swordsmen who will never actually use our weapons to their intended purpose, trained by a previous generation of swordsmen who likewise never actually used their weapons, etc., etc.. Like an endless legion of pilots who will never venture beyond the flight simulator, our grasp of our chosen discipline is profoundly 
constrained. We cannot even fathom how much we do not know. We train as best we can from those sources that have survived, uncertain how far we have drifted from the historical realities of fighting in earnest with swords.

What is the best way to train for the actual use of a sword?

- Drills in the salle?

- Strength and flexibility conditioning in the gymnasium?

- Test cutting?

- Sparring?

- Tournaments?

For thousands of years, the unequivocal answer to this question has been:

- None of the above

Rather, the answer has been...

\section{HUNTING}

Certainly, this was not the modern hunting paradigm of sitting concealed somewhere with a firearm, waiting for game to happen by. Hunting was synonymous with "the chase" -- the pursuit of large, often dangerous game over natural terrain with dogs and weapons of war: spear, sword and bow.

Since antiquity, hunting has been regarded as an excellent means of training men for war. Although the specific areas of emphasis vary from one source to the next, the tone is surprisingly consistent over the course of two millennia. Again and again, seasoned commanders wrote more highly of hunting than of any other method as training for the profession of arms. Any means of training held in such high regard for so long a time is well worth a closer look by modern historic Western Martial Artists.

The Greek historian Xenophon (430 - 354 B.C.) was an accomplished mercenary soldier and military leader. After the death of his commander Cyrus the Younger at the Battle of Cunaxa and the treacherous slaughter of numerous Greek generals and captains at the peace conference that followed, Xenophon emerged as a leader of the Ten Thousand, the remnants of the defeated mercenary army. He helped lead them through more than 500 miles of hostile territory to the Black Sea coast and relative safety. (Hornblower and Spawforth, 1998: p. 880-884) In addition to recounting the events of this Persian expedition in Anabasis, Xenophon wrote many other works, including $\underline{\text { On }}$ Hunting. He devoted a substantial portion of this treatise (an excerpt of which follows) to the benefits of hunting as training for war.

Enthusiasts for this sport (bunting) will be benefitted in many ways. For it promotes good health, improves sight and hearing, delays old age, and especially trains men for war.

First, when they march under arms on difficult roads, they will not become exhausted, for they will tolerate the hardship from having learnt to carry weapons for catching wild 
beasts. Secondly, they will be able to sleep rough and to be good guards of whatever they are instructed to watch over. And in their approach to the enemy they will be able simultaneously to attack and to obey orders because this is how they themselves catch their quarry. If drawn up in the front line they will not leave their station because they are able to hold firm. If the enemy are routed, they will pursue their opponents in good order and with safety whatever the ground because of their previous practice. And if their own army has suffered a reverse in ground that is wooded or precipitous or difficult in some other way they will be able both to save themselves without dishonour and to save others; for familiarity with the situation will give them a mental advantage. And it has happened in the past that some men of that kind, when a large force of allies had been turned to flight, and the victorious enemy had lost their way because of the difficulty of the terrain, by their own fitness and self-confidence have fought back and turned them to flight; for it is always the case that those in a good physical and psychological state are close to success.

(Phillips \& Willcock, 1999: p. 81-83)

Vegetius (circa 400 A.D.), author of Epitoma rei militaris, the only ancient Roman military manual to survive intact, was both more blunt and more emphatic.

Fishermen, fowlers, pastrycooks, weavers and all who shall seem to have dealt with anything pertaining to textile-mills should in my view be banned far from the camp. Masons, blacksmiths, wainwrights, butchers and stag-and boar-hunters may usefully be joined to the military. This is a matter on which the entire safety of the State depends, that recruits be levied who are outstanding both in physique and moral quality.

(Milner, 1993: p. 7-8)

Charlemagne, an indefatigable commander who enjoyed unparalleled military success, was also an enthusiastic advocate of hunting. (Dixon, 1976: p. 99-106) In his biography of Charlemagne ( 740s - 814 A.D.), the contemporary chronicler Einhard noted that "As soon as they were old enough he (Charlemagne) had his sons taught to ride in the Frankish fashion, to use arms and to hunt." (Thorpe, 1969: p. 74). Of Charlemagne himself, Einhard wrote "He spent much of his time on horseback and out hunting, for it came naturally to him, for it would be difficult to find another race on earth who could equal the Franks in this activity." (Thorpe, 1969: p. 77). Notker the Stammerer, another contemporary source, spoke of Charlemagne's hunting exploits include hunting bison and wild oxen from horseback with his sword (Thorpe, 1969: p. 144).

Majorcan philosopher Ramon Lull (1232 - 1314 A.D.) wrote that knights should "hunt harts, bears and other wild beasts, for in doing these things, the knights exercise themselves to arms and thus maintain the order of knighthood.(Price 2001: p. 30)

As cited at the beginning of the article, Alfonso XI of Castile (1312 - 1350 A.D.) was unequivocal: hunting was the best training for war. Best known for his victory at Rio Salado that stymied the last major Muslim invasion of Spain, his military efforts 
reinvigorated the Reconquista. Following his untimely death from Plague at the age of thirty-nine while besieging Gibraltar, the cause lost momentum until the 15th century. (O’Callaghan, 1975: p. 411-412)

John I of Portugal (1358 - 1433 A.D.), who all but annihilated the Castilian army at the Battle of Aljubarrota -- and his son \& successor Dom Duarte (aka Edward, King of Portugal 1391 - 1438) both unequivocally endorsed hunting as fundamental training for war. (O’Callaghan, 1975: p. 533) (Cummins, 2001: p. 4) (Preto \& Preto, 2006: p. $162-$ 172) Why? Because the skill set necessary for "the chase" was very similar to that required for combat -- and significantly different from that required for the artificial and increasingly regulated faux combat of the tournament.

Especially when limited to "individual combat", sparring for points with blunted weapons in a limited, well defined area with a flat, dry surface constituted little more than an elaborate game of "weapon tag" performed for purposes of personal vanity and entertainment. The cognitive, psychological and physical demands of hunting, like war, were far greater than those required for the tournament.

At this point, some might reasonably contend that even if the argument is valid, that is to say:

\section{that the chase is the best possible training for actually using a sword}

the matter is academic, as there is no way to recreate this training in modern times. For many countries, they would be correct. In significant portions of the United States, however, hunting feral swine with dogs and primitive weapons is not only legal, but actively encouraged by local governments. (Mississippi State University, 2014)

Sus scrofa (wild boar) are not native to North America. Spanish explorers introduced domestic swine to the continent in the 16th century. A combination of free range husbandry practices and escapes resulted in the establishment of a vast feral hog population. In the early 20th century, Eurasian (aka Russian) wild boar were introduced to some areas of the U.S., with subsequent escapes augmenting the existing gene pool, resulting in significant increases in the physical size and aggressiveness of some feral swine populations. (Mississippi State University, 2014) More recently, this process has been accelerated by escapes of Eurasian breeding stock from game farms, as well as the deliberate (illegal) capture, transportation and release of feral swine to establish populations in new areas. Current estimates place the nationwide total feral hog population in the U.S. at more than 5 million. (Florida Fish and Wildlife Conservation Commission, 2014).

Because wild boar are an invasive, non-native species highly destructive of indigenous flora and fauna, wildlife management officials actively encourage wild boar eradication efforts. While hunting many other forms of large game with dogs has been severely restricted or prohibited in the U.S. within the last 50 years, boar hunting with dogs is still quite common. (Triplett, 2004: p. 36-41) In some areas, the practice is so well 
established that there are commercial guides with the specially trained "hog dogs" (Alabama Department of Conservation and Natural Resources, 2014), some of which wear modern Kevlar armor quite similar to that depicted in Late Medieval / Renaissance primary sources. (Woolley, 2002: p. 42)(Baillie-Grohman, 2004: p. 79)

Historical hunting enthusiasts have taken full advantage of this opportunity, pursuing medieval style boar hunts dressed in period attire, employing replica weapons and hunting techniques described in period manuals to recreate as closely as possible "the chase". (Bourjaily, 2011). The following observations have been gleaned by the authors from organizing and participating in numerous medieval style hunts, resulting in the successful harvest of more than two dozen wild boar with dogs, bows, crossbows, swords, spears and daggers. (Wilburn, 2008 - 2013).

\section{UNDERSTANDING THE HUNT}

So what is it like to hunt wild boar in medieval fashion with dogs, bows, spears and swords? With the exception of the horse (we always hunt on foot), the modern translation of this excerpt from the 14th century Arthurian romance Sir Gawain and the Green Knight is surprisingly accurate.

While the lord was racing over the fields, After the ferocious boar that rushed up Hillsides and broke the backs of his best Hounds, boled in till arrows drove bim On, out of shelter, to run In the open -- arrows falling like flies On bis bide. He beld them off, leaping Wild, until at last running Was over and, weary, he worked his way To a rocky hole over a river, The hill was behind him; his hooves pawed At the ground, foam grimaced on his snout; And he sharpened his tusks, waiting. Tired And still afraid, the bunters stood safely

To the side; they wanted to annoy bim, but no one Came near:

So many had been gored

By those tusks that fear

Of being torn

Held them: he seemed wild, be seemed weird.

And then the lord rode up, urging

His horse, and saw bim holed in and his hunters

Watching. He jumped ligbtly down, drew

His bright-polished sword and began to approach him,

Hurrying across the ford to bis bole.

And the boar saw him, saw his bright sword,

And his hackles rose, and he snorted so loud 
That the bunters were afraid for their lord's life.

Then the beast rushed out at him, straight and quick,

And man and boar blended in the steaming

White water; but the boar had the worst, for the lord

Had measured his charge, and aimed his sword

Into his throat, and planted it deep,

Down to the bilt, so the heart was cut,

And snarling as he fell the boar surrendered

And dropped.

from Part III

Sir Gawain and the Green Knight

(Raffel, 2001: p. 96 - 97)

Once scented by the hounds, the boar will usually run in search of shelter. If pressed hard, he may seek water, turn to fight, or both. When fighting, boars prefer to have trees, embankments or other obstacle behind them to prevent being flanked. All the behaviors described (pawing, foaming, clashing tusks, snorting, etc.) are quite common. The sudden, forceful charge is classic. The full force of such a charge received on a sturdy boar spear while employing textbook technique can easily throw a 200 pound man 6 feet backwards through the air.

\section{COGNITIVE TASKS}

Beyond the obvious logistical tasks of planning for and supplying a sizable, mobile party of hunters for days, there are a great many cognitive tasks necessary for medieval style hunting that are required less so, if at all, for the tournament.

- Locating one's "enemy" (the quarry -- whether an individual or group)

- Pursuing the "enemy" -- sometimes for hours or even days

- Navigating through difficult terrain \& learning to use terrain to one's advantage

- Remaining in contact / communicating with friendly forces

- Coordinating movements of friendly forces to alter the behavior of the "enemy"

- Avoiding accidental injury to friendly forces

While at first glance these points may appear tangential, they illustrate how profoundly the modern WMA training paradigm neglects fundamental skills of actual swordsmanship. Consider (but do not try) the following pre-sparring warmup:

Jog for half an hour

Together with a group of friends

Cross-country -- not using trails

Pursuing several other runners who may not stay together

While carrying large sharp objects that can easily accidentally injure you or your friends 
Most modern Western Martial Artists have little if any experience with this most basic of tasks, safely carrying an actual weapon in the field. Running over broken terrain with a lethally sharp object, especially in a group, dramatically alters both the mindset and the behavior of any sane being. Doing so in complex, unpredictable circumstances provides innumerable insights into swordsmanship not readily attainable by any other means.

\section{PSYCHOLOGICAL TASKS}

Enduring physical hardship develops mental toughness and self confidence. This truism has been the basis of military training from antiquity. Sleeping rough, eating and drinking only what you can carry, walking or running over hills and valleys, stalking through forests and swamps, facing the bites and stings of countless insects, abiding rain, sleet and snow all while carrying a weapon ready for action develops a warrior mindset (Milner, 1993) -- a world away from the temperature controlled gymnasiums in which most modern Western Martial Artists train and compete.

Facing real threat of injury dramatically alters behavior. Safety is a laudable goal, and Western Martial Arts enjoy a safety record comparable to that of other modern combative sports. Unfortunately, it is this very safety that undermines a realistic understanding of actual swordsmanship -- by its nature, a profoundly unsafe activity. Modern protective equipment and specially engineered weapon simulators have made WMA so safe that failure has few if any consequences. Wild gambits and haphazard ploys that might well result in dismemberment or death in an actual swordfight don't even leave a bruise. When such foolhardy assaults have no significant consequences, the predictable result is reckless aggression.

This schoolhouse mindset is not new. In 1599, Master of Defence George Silver lamented that some of his colleagues "have taken upon them to stand upon Schooletrickes and jugling gambolds" (Wagner, 2003: p. 205). Silver's contemporary, William Shakespeare, through his tragic hero Hamlet noted the consequences of failure in a bout quite casually. "I'll gain nothing but my shame and the odd hits." (Staunton, 1991: p. 394 - Act V, Scene 2.)

Profound respect (bordering on mortal fear) of the opponent's blade has been lost. When fighting for real, letting even a single blow through might result in serious injury or death. Proper regard for one's own blade is also missing. Mishandling a sharp weapon can easily result in accidental maiming of oneself or one's comrades. Individuals who survive in conflict ridden environments long enough to become experienced fighters are likely to rely on conservative techniques that emphasize personal safety at least as much as effective engagement of the enemy. (Grossman, 2007)

Numerous premodern authors speak of hunting as a means of conditioning individuals to control fear. Why? Because fear profoundly affects physiology and behavior. In his text On Combat, LTC Dave Grossman deals at length with physiologic response to injury / threat of injury -- describing a color coded spectrum of zones of response: yellow, red, grey and black. (Grossman, 2007. p. 30-49) 
When fear is controlled (yellow zone and to some extent red zone), visual and cognitive reaction times improve over baseline levels while fine motor control is preserved. At the upper end of the red zone, complex fine motor skills deteriorate while gross motor skills are enhanced: charging \& running (the traditional "fight or flight" paradigm). For those within the grey and black zones, vision and hearing become distorted and irrational behaviors, freezing, submissive behavior, even loss of continence of bowels or bladder are likely to occur.

Colonel Grossman reaffirms what has been recognized since Xenophon -- that training under realistic conditions with an actual or perceived physical threat can habituate individuals to stress, increasing their ability to optimize future performance by controlling their fear to remain in the yellow and red zones of improved cognition and reaction times -- and by staying out of the grey and black zones with their loss of fine motor skills, situational awareness and self control.

\section{PHYSICAL TASKS}

General physical conditioning and fitness are important to the pursuit of any combative sport. Activity specific stamina, however, is essential. Doing 500 situps without stopping is an admirable achievement, but it is far less important than the ability to keep one's weapon effectively in play for an hour or more. As Xenophon commented, hunting requires individuals to become accustomed to carrying their weapons for long periods of time. (Phillips \& Willcock, 1999: p. 81-83) Holding / carrying a sharp sword or spear ready for action for an hour or more conditions (and fatigues) different muscles, changing how one subsequently uses the weapon.

Some WMA practitioners engage in test cutting, most often with stationary, fairly soft, homogenous targets such as rolled tatami mats. While this practice provides useful insights into blade control, the information gleaned therefrom has limited applicability. Real enemies move ... quickly. They may be armored. Even when a blade strikes true, it may deflect or twist in the hand as it encounters various densities. Sharp blades behave very differently when used against living, moving flesh and bone.

Grisly as it sounds, the essence of swordsmanship is a practical understanding of the forcible application of an edged weapon to quickly incapacitate or kill a living opponent. (Grosz \& Janich, 2006). Countless hours of training in the handling of a sword are spent simply to approach this ultimate goal. Medieval style boar hunting introduces the swordsman to the realities of actually using an edged weapon to lethal effect.

Targeting and force are crucial. Even the most inexperienced Western Martial Arts novice can appreciate the absurdity of equating a toe stab or a wrist flick with a powerful thrust to the head or body in sparring, but some sword games count these as hits of equal worth. (Federation Internationale D'Escrime, 2014) When boar hunting, no such inanity applies. Blows of insufficient force or thrusts to non-vital areas are less than worthless, as they serve only to further enrage the boar while exposing the hunter to serious peril. A thrust to the chest against a moving target off by as little as an inch 
may bounce harmlessly off the boar's notoriously tough shoulder blade, while a weapon blade not angled in line with the ribs or thrust weakly may fail to penetrate any vital structure.

Multiple blows (cuts or thrusts) were often required. Simple sword thrusts, particularly from narrow bladed weapons such as rapiers, were not necessarily even incapacitating. In his Paradoxes of Defence (sic) published in 1599, George Silver made the following observation.

I have knowne a Gentleman hurt in Rapier fight, in nine or ten places through the bodie, armes, and legges, and yet hath continued in his fight, \& afterward hath slain the other, and come home and hath bene cured of all bis wounds without maime, \& is yet living. But the blow being strongly made, taketh sometimes cleane away the hand from the arme, hath manie times bene seen. Againe, a full blow upon the head or face with a short sharp Sword, is most commonly death. A full blow upon the necke, shoulder, arme, or leg, indangereth life, cutteth off the veines, muscles, and sinewes, perished the bones: these wounds made by the blow, in respect of perfect healing, are the losse of limmes, or maimes incurable forever.

(Wagner, 2003: p. 217-218)

Even when an eventually mortal blow is struck, the fight is not necessarily finished. (Grosz \& Janich, 2006) History is replete with examples of individuals sustaining numerous, often horrific injuries before succumbing. The following is from an eyewitness account of the murder of Archbishop of Canterbury Thomas Becket in 1170.

"As to the fifth, no knight but that clerk who had entered with the knights, that a fifth blow might not be wanting to the martyr who was in other things like to Christ, be put his foot on the neck of the boly priest and precious martyr, and, horrible to say, scattered his brain and blood over the pavement, calling out to the others, 'Let us away, knights; he will rise no more.'

Edward Grim

(Eyewitness to History.com, 1997)

It is worth noting that it took 4 blows to finish an unarmed, unarmored man who was not defending himself -- and that the last of Becket's assailants went to the trouble of scooping out the fallen man's brains (the 5th blow) to ensure that he did not survive. The assailant knew that it took not just multiple blows, but the deliberate, knowledgeable and systematic application of force to vital structures to truly finish his opponent.

Like humans, wild boar often require multiple non-survivable wounds before they are incapacitated. (Triplett, 2004: p. 189-191). Boar have been known to leap back up and continue fighting even after apparently having been killed. Wounded opponents (humans and animals) may continue to move and fight for seconds to minutes after 
receiving one or more unquestionably mortal wounds. (French, 1996) Delivering multiple lethal blows in rapid succession, then employing ones weapon to restrain or hold an opponent at bay (be he boar or man) until he expires of his wounds is a critically important skill that is absent from the WMA lexicon.

Although best known for his Livre de Chasse, Gaston III, Count of Foix (better known as Gaston Phebus) proved a formidable military commander who amassed a vast fortune from his victory at the Battle of Launac. (Fowler, 2001: p. 61-68) In the context of boar hunting, Gaston Phebus was more conservative than his Iberian brethren (Alfonso XI, John I of Portugal, Dom Duarte) -- advocating the use of a spear or sword from horseback, or failing that, the use of a spear (not a sword) when on foot. Phebus was quite clear about where to target the boar when inflicting a mortal wound -- from behind (the shoulder blade) into the heart (and lungs).

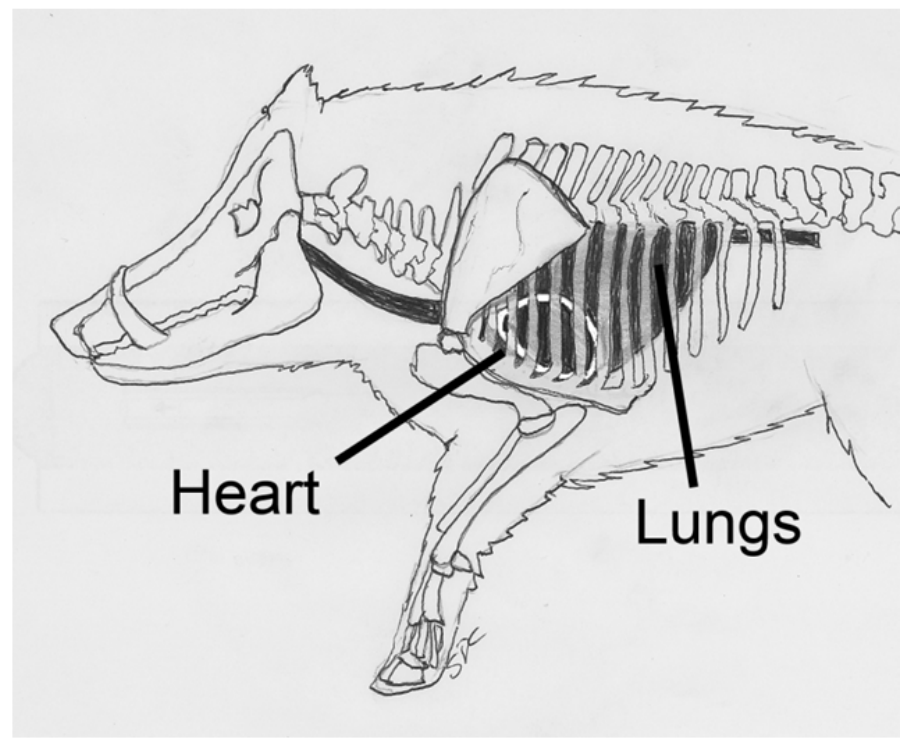

Diagram 1

When mounted, Phebus unequivocally recommended riding off rather than trying to keep the blade (sword or spear) engaged with the target. His advice when hunting on foot was quite different.

If one dares attack a boar in his den one should do so with a 'barred' spear, i.e. one that is equipped with a crossbar below the head, or 'winged', to prevent the weapon from entering too deep, thus enabling the bunter to keep out of range of the boar's deadly tusks. For the same reason one should grip the shaft in the middle and not near the head. If the boar is attacking one must not couch the spear but wield it with both fists. But if the bunter has struck one should couch the spear and with all one's might press against the boar. If the beast is stronger than the bunter, the latter should change 
from one side to the other but not for a moment relax his hold, and keep pushing until God or men come to bis aid.

(Schlag, 1998: p. 58-59)

Manipulation of the blade after its placement in a vital area is key not only to neutralizing the opponent, but also to remaining uninjured. Understanding how to manipulate the blade to cause maximal injury once on target is tremendously important -- as is the understanding of how to employ the blade to prevent the (often mortally) wounded opponent from returning the favor. (Schlag, 1994: p. 58-59) Although somewhat simplistic, these actions may be thought of primarily as

movement within the plane of the blade movement perpendicular to / across the plane of the blade

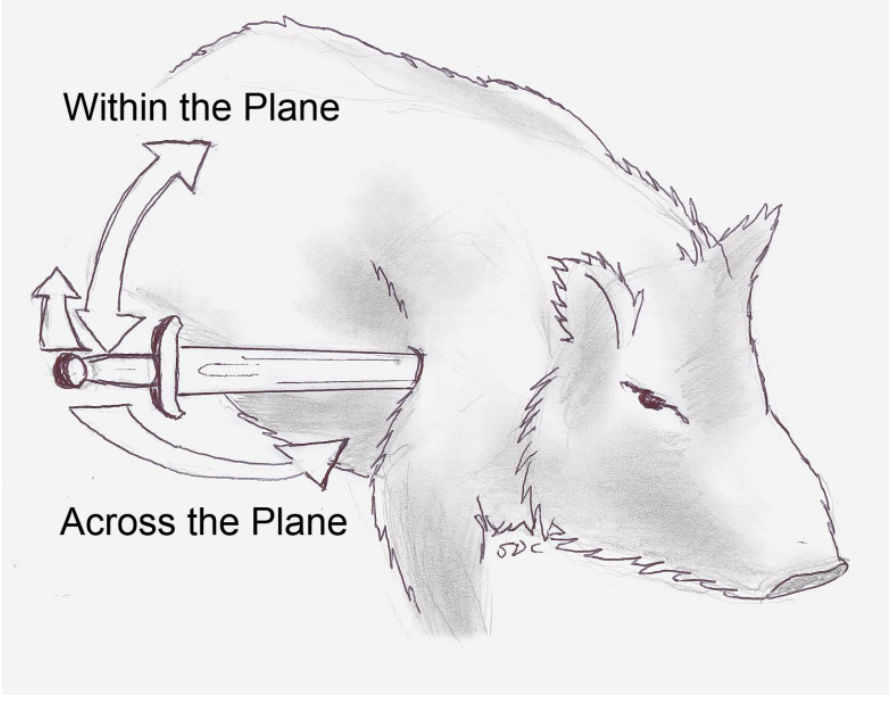

Diagram 2

Rotation of the blade along its axis is not especially practical for spears or wide bladed swords, but has been described as a means of deliberately, significantly increasing the severity of injury caused by narrow bladed swords in the 19th century. (Amberger, 1998: p. 103).

Movement within the plane of the blade turns a simple thrust into a cut. A simple thrust to the chest, especially from a fairly narrow blade such as a rapier, may well be survivable (Grosz \& Janich, 2006), sometimes even without modern medical care. Such was the case in many pre-modern duels. (Hutton, 2003). A thrust to the chest to which a forceful pushing or levering motion is subsequently applied creates a great deal more 
damage. Such a wound is much more likely to be rapidly incapacitating or fatal. (Grosz \& Janich, 2006).

Movement across the plane of the blade (i.e. roughly perpendicular) will cause additional damage, but its primary benefit is to force the opponent in the direction the swordsman chooses. For example, if a boar is thrust in the chest behind the shoulder (blade roughly perpendicular to the ground), pushing the hilt of the sword sideways toward the boar's head forces the shoulder blade forward, preventing the boar from turning its head to slash the swordsman's legs with its tusks. For a boar similarly impaled by a spear, raising the butt of the spear (either within or perpendicular to the plane of the blade) above the hunter's head may topple the boar outright -- and regardless prevent the boar from closing with the hunter. While these actions may be tolerated by strong spears and stout swords, attempting such maneuvers with narrow blades such as rapiers or small swords would likely result in the blades bending or breaking. (Kirchner, 2004), (Hutton, 2003).

Sound far-fetched? Dom Duarte devotes $20+$ pages to techniques intended to maximize injury to man or beast with lance, javelin and sword, (Preto \& Preto, 2006) commenting at one point:

And all these bunting techniques are very useful in combat because a skilled bunter strikes well with the spear, causing deeper wounds on the enemy's body.

\section{CONCLUSIONS}

... for bunting is a training for all types of fighting met with in war; against a foe crossing in front, in a bead-on encounter or in a pursuit; in an awkward situation or a sounder one. For every kind of military encounter, hunting is a better training than jousting. If the tourney teaches a man how to strike with a sword on a belmet, how much better he will learn by striking down a boar when his only chance of saving bimself is by a good thrust with the spear.

King John I of Portugal (1385 - 1433 A.D.) Livro da Montaria (Hunting Book of John I) (Cummins, 2001: p. 102)

Despite the best of intentions, many currentpractices within Western Martial Arts training and competition actively subvert the realistic study of swordsmanship. Hunting using replica weapons and techniques provides valuable insights into the cognitive, psychological and physical aspects of medieval combat not available through standard modern Western Martial Arts training.

\section{Cognitive - Think Differently}

Medieval style boar hunting as a form of training forces the participant to move beyond the game mentality of martial sport. "Right of way" is spurious. "Late hits" injure or kill just as thoroughly as a "first blow". The imperative is to strike without being struck. Anything less is folly. 


\section{Psychological - Understand Differently}

Sword-play is not swordsmanship. Without a real threat of injury, even the most well researched recreation of Western Martial Arts is little more than an elaborate game of "sword tag". Controlling ones fear while employing sharps with lethal force in a medieval style boar hunt fundamentally alters one's understanding of medieval weapons $\&$ techniques.

\section{Physical - Behave and Teach Differently}

Strive to study and teach swordsmanship -- not mere sword-play.

Respect the blade as if it were lethally sharp.

Train on natural surfaces. Train against multiple opponents. Train with unhalted bouts.

Train to overwhelm an opponent with a continuous assault of well targeted blows.

Train to assume a defensive lying whenever a halt is called.

Train to use your sword as an actual weapon -- as if your life depended on it.

\section{POST SCRIPT}

The taking of life, whether in hunting, self defense or war should NEVER be treated lightly. For all but the most serious and mature of students of swordsmanship, I actively discourage the pursuit of medieval style boar hunting. For those few with immense commitment and clarity of purpose, I urge that the matter be approached with the great caution. Medieval style boar hunting is a profoundly dangerous form of training.

Even as medieval hunters honored their prey with the curée - an elaborate ritual following a successful hunt - (Baillie-Grohman, 2005), modern hunters should treat their quarry with dignity and respect, using every part of the animal possible while disposing of any remains as befits a worthy opponent. Consider giving a portion of the meat from successful hunts to the poor.

Medieval style boar hunting is an extremely intense physical and psychological experience which will permanently change the hunter: both how he perceives and how he is perceived by others. Hunting in this fashion fundamentally alters not only one's perception of modern WMA training, but also one's understanding of the very nature of swordsmanship. 


\section{BIBLIOGRAPHY}

Alabama Department of Conservation and Natural Resources, 2014. Control Methods for Feral Hogs. [online] Available at:

http://www.outdooralabama.com/hunting/hunterresources/articles/fhcontrol.cfm. [Accessed 10 Jan 2014].

Alfonso XI of Castile., 1877. Libro de la Monteria Del Rey D. Alfonso XI, Volumes 1 \& 2.

[printed transcription of manuscript] Biblioteca Venatoria de Gutierrez de la Vega. Madrid. Impresor de Camara de S. M.

Amberger, J. C., 1999. The Secret History of the Sword: Adventures in Ancient Martial Arts. USA. MultiMedia Books, Inc.

Anderson, W. F., 2006. Forensic Analysis of the April 11, 1986, FBI Firefight. Boulder. Paladin Press.

Anonymous. Sir Gawain and the Green Knight. Translated from Middle English by Raffel, B., 1970. Published 2001. New York. Signet Classic.

Baillie-Grohman, W. A., 2004. Sport in Art: An Iconography of Sport Illustrating the Field Sports of Europe and America from the 15th to the End of the 18th Century. Honolulu. University Press of the Pacific.

Baillie-Grohman, W. A. and Baillie-Grohman, F. N. eds., 2005. The Master of Game by Edward of Norwich. Philadelphia. The University of Pennsylvania Press.

Bourjaily, P., 2011. Gettting Medieval: Serious Hunting With Gear From the Middle Ages. [online] Available at: http://www.fieldandstream.com/photos/gallery/gear/huntinggear/2011/08/getting-medieval-serious-hunting-gear-middle-ages?photo=0\#node1001451392. [Accessed 10 Jan 2014].

Cummins, J., 2001. The Hound and the Hawk: The Art of Medieval Hunting. 2nd ed. London: Phoenix Press.

Dixon, P., 1976. The Making of the Past: Barbarian Europe. New York. E.P. Dutton \& Company, Inc. Eyewitness to History.com, 1997. The Murder of Thomas Becket, 1170. [online] Available at: http://www.eyewitnesstohistory.com/becket.htm. [Accessed 10 Jan 2014].

Federation Internationale D’Escrime, 2014. FIE Rules for Competitions: Book 1, Part 3. Epee: The Conventions of Fencing. [online] Available at: http://www.fie.ch/download/rules/en/book t jan_2014.pdf. [Accessed 10 Jan 2014].

Florida Fish and Wildlife Conservation Commission, 2014. Wild Hog. [online] Available at: http://myfwc.com/hunting/by-species/wild-hog/. [Accessed 10 Jan 2014].

Fowler, K., 2001. Medieval Mercenaries -- Volume 1: The Great Companies. Malden, Massachussetts. Blackwell Publishers, Inc.

Grossman, D. and Christensen, L., 2007. On Combat: The Psychology and Physiology of Deadly Conflict in $W$ ar and in Peace. USA. PPCT Research Publications.

Grosz, C. and Janich, M., 2006. Contemporary Knife Targeting: Modern Science vs. W. E. Fairbairn's Timetable of Death. Boulder. Paladin Press.

Hand, S. ed., 2005. SPADA 2: Anthology of Swordsmanship. Highland Village, Texas. The Chivalry Bookshelf.

Hornblower, S. and Spawforth, A. eds.,1998. The Oxford Companion to Classical Civilization. Oxford. Oxford University Press. 
Hutton, A., 2003. The Sword and the Centuries. London. Greenhill Books.

John I of Portugal., 1918. Livro da montaria, feito por D Joao I, rei de Portugal, conforme o mauscrito $n$. 4352 da Biblioteca Nacional de Lisboa; pub por ordem da Academia das Sciencias de Lisboa. [printed transcription of manuscript] Biblioteca Nacional de Lisboa. 4352. Coimbra. Impresa da Universidade.

Kirchner, P., 2004. Dueling with the Sword and Pistol: 400 Years of One-on-One Combat. Boulder. Paladin Press.

Lebaud, P. ed., 1986. Le Livre de la Chasse: Texte integral traduit en francais moderne par Robert et Andre Bossuat. Paris. l'Imprimerie Marcel Bon a Vesoul.

Milner, N. P., 1996. Vegetius: Epitome of Military Science. Liverpool. Liverpool University Press.

Mississippi State University, 2014. Wild Pig Info. [online] Available at: http://wildpiginfo.msstate.edu. [Accessed 10 Jan 2014].

O’Callaghan, J. F., 1975. A History of Medieval Spain. Ithaca, New York. Cornell University Press.

Phébus, G. Livre de chasse, édité avec introduction, glossaire et reproduction des 87 miniatures du manuscrit 616 de la Bibliothèque nationale de Paris par Gunnar Tilander, Karlshamn, Johansson (Cynegetica, 18), 1971 [réimpr.: 1976; Graz, Akad. Druck, 1994], 453 p.

OR

Schlag, W. ed., 1998. Manuscripts in Miniature: The Hunting Book of Gaston Phebus. Manuscrit francais 616, Paris, Bibliothèque nationale. London. Harvey Miller Publishers.

Phillips, A. A. and Willcock, M. M. , 1999: Xenophon \& Arrian on Hunting with Hounds. Warminster, UK. Aris \& Phillips, Ltd.

Preto, A. F. and Preto, L., 2006. The Art of Riding on every Saddle by Dom Duarte, King of Portugal -Medieval Horsemanship: Equitation, Hunting and Knightly Combat with Lance and Sword. Highland Village, Texas. The Chivalry Bookshelf.

Price, B., 2001. Ramon Lull's Book of Knighthood and Chivalry \& the Anonymous Ordene de Chevalerie. Highland Village, Texas. Chivalry Bookshelf.

Shakespeare, W., 1991. Hamlet. (The Complete Illustrated Shakespeare: Volume 3) Staunton, H. ed., Ware, UK. Wordsworth Editions, Ltd.

Thorpe, L., 1969. Einhard and Notker the Stammerer: Two Lives of Charlemagne. London. Penguin Books.

Triplett, T., 2004. The Complete Book of Wild Boar Hunting: Tips and Tactics That Will Work Anywhere. Guilford, Connecticut. The Lyons Press.

Wagner, P., 2003. Master of Defence: The Works of George Silver. Boulder. Paladin Press.

Wilburn, P., 2013. St. Hubert's Rangers: Brotherhood of the Medieval Hunt. [online] Available at: http://www.sthubertsrangers.com. [Accessed 10 Jan 2014].

Woolley, L., 2002. Medieval Life and Leisure in the Devonshire Hunting Tapestries. London. V \& A Publications. 